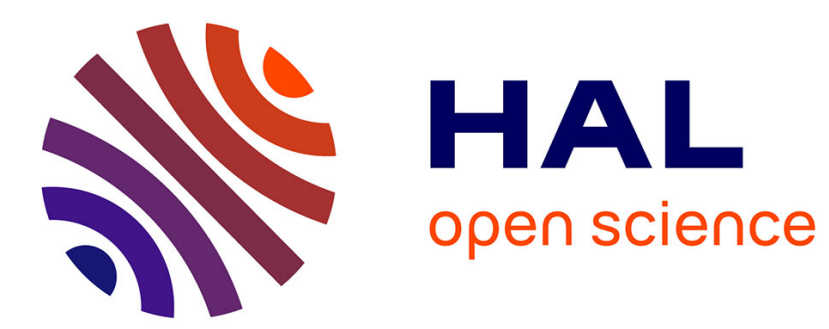

\title{
The fourth stage of social democracy
}

\author{
Roberto Frega
}

\section{To cite this version:}

Roberto Frega. The fourth stage of social democracy. Theory and Society, 2021, 50 (3), pp.489-513. 10.1007/s11186-020-09424-y . hal-03484664

\section{HAL Id: hal-03484664 https://hal.science/hal-03484664}

Submitted on 17 Dec 2021

HAL is a multi-disciplinary open access archive for the deposit and dissemination of scientific research documents, whether they are published or not. The documents may come from teaching and research institutions in France or abroad, or from public or private research centers.
L'archive ouverte pluridisciplinaire HAL, est destinée au dépôt et à la diffusion de documents scientifiques de niveau recherche, publiés ou non, émanant des établissements d'enseignement et de recherche français ou étrangers, des laboratoires publics ou privés. 


\title{
The Fourth Stage of Social Democracy
}

\author{
Roberto Frega \\ (Forthcoming in Theory and Society, accepted November 23 $\left.3^{\text {rd }}, 2020\right)$
}

\begin{abstract}
This paper examines the political crisis of social-democratic parties in Western Europe in light of its impact on the social-democratic emancipatory project, and asks whether the first calls the second into question. It begins by defining social democracy as an emancipatory project, and identifies three major historical phases which correspond to three distinct conceptions of the project. Section two examines recent literature in comparative welfare state economics, political sociology, and studies of populism and authoritarianism, to show how the socio-economic transformations of the last five decades have enlarged and fragmented the constituency of social-democratic parties, and contends that this situation has generated powerful tensions between the normative and the mundane dimensions of the social-democratic project. Three major dilemmas - economic, cultural, and political - leading to three deep conflicts internal to the social-democratic constituency are identified and discussed. Combining these empirical findings with the three rival interpretations of the social-democratic project introduced in section one, section three develops three possible scenarios for the evolution of this project in the near future: decline, drift, and renewal. Section four assesses the likelihood and political meaning of each scenario for the pursuit of the social-democratic project, taking into consideration the recent upsurge of left-wing populism.
\end{abstract}

Keywords Democratic theory, New left, Populism, Social democracy, Socialism

In the last two decades social-democratic parties have suffered their heaviest historical losses in most OECD countries (Benedetto, Hix, and Mastrococco, 2020, Berman and Snegovaya 2019). Whether in terms of government seats, number of elected MPs, share of electoral vote, whether we focus on western Europe, the EU, or the OECD, what we face today is a state of extreme weakness and vulnerability which affects the practice as well as the idea of social democracy. The socialdemocratic project is challenged from all sides of the political spectrum. On the one hand, in recent decades traditional conservative parties have suffered a lesser crisis than traditional social-democratic parties. On the other, new left-wing populist parties are eroding the social base of social-democratic parties .

The spread, speed, duration, and direction of this trend is such that one is entitled to ask whether what is at stake is not only the fate of a particular family of political parties but, more radically, whether the most successful project of social and political 
emancipation the western world has known in the last two centuries itself is at risk. Deciding whether this is the case requires a clear understanding of what has occurred in terms that go beyond the mere analysis of electoral trends, in order to grasp their normative implications. Within the plethora of publications on the social-democratic crisis, it is common to blame recent social-democratic convergence to the center and allegiance to the neo-liberal project ${ }^{1}$. In so doing, so the criticism goes, socialdemocratic parties would have abandoned their original constituency and paved the way for the rise of the populist backlash. The political implication of this diagnosis is that returning to the status quo ante practices of Keynesian redistribution would rejuvenate the social-democratic project, reinstating it on the right track of its uniquely legitimate trajectory.

While widespread, this narrative is, however, empirically inaccurate and theoretically oversimplified. Indeed, as political sociologists have shown, the socialdemocratic decline began much earlier and reflected different sets of causes. As data show, social-democratic electoral success in Europe peaked shortly after World War II, remained stable till the mid-1960s, knew a sudden and unexpected rejuvenation under the slogan of the "third way", and then begun a process of slow but steady decline, mitigated only by the later affirmation of social democracy in southern European countries (Benedetto, Hix, and Mastrococco, 2020; Merkel et al., 2008; Bartolini, 2000). But this narrative also suffers from two additional shortcomings. At the normative level, it endorses a view of social democracy that is outdated, tied to a bygone spatiotemporal configuration of the social-democratic trajectory. At the empirical level, it underestimates the impact of the social and cultural transformations that have characterized the transition from industrial to post-industrial society, triggering the deep change of emancipatory expectations and the ensuing expansion of social democracy's social base. These two phenomena are strongly related, as the socio-economic transformation has implied, in turn, a profound reconfiguration of the normative core of the social-democratic project itself. Understanding the crisis of social democracy requires, therefore, that its trajectory be examined not only in light of mundane party strategies, but also in light of the historical evolution of social democracy's ideational normative core. In this paper, By “ideational”, I refer to social democracy as a set of normative commitments, whereas by "mundane" I refer to social democracy as a set of political actors and strategies that seek political power, mainly through political competition.

Taking the entanglement of the ideational and mundane dimensions of the socialdemocratic project seriously provides, I contend, a fresh perspective with which to interpret the present crisis of the social-democratic project, a crisis that depends, precisely, on the multi-dimensional disalignement between these two dimensions rather than on a single causal factor such as the oft-lamented retreat from

Standard accounts include Streeck (2014); Crouch (2004); Wallerstein et al. (2013), and more recently, Berman and Snegovaya (2019) and Mudge (2018). 
redistributive policies. The major implication of this approach, as I intend to show, is that economic explanations of social democracy's crisis which dominate contemporary debates ${ }^{2}$ are incomplete and short-sighted, since they ignore the political implications of the complex entanglement of the ideational and the mundane. In other words, even though a view of economy - let us call it "egalitarian" or "redistributive" - must remain a central pillar of the social-democratic emancipatory project, for the reasons discussed in this paper sticking to a mere economic program is no longer sufficient to pursue the project. Yet the simple addition of socio-cultural and political dimensions to the economic will not provide a viable solution, which explains why the social-democratic project is actually caught in a threefold dilemma which jeopardizes its survival .

The paper proceeds as follows. Section one provides a definition of the socialdemocratic project, distinguishing three major phases which correspond to three distinct normative conceptions. Section two examines recent literature in comparative welfare state economics, political sociology, and studies of populism and authoritarianism to show how socio-economic transformations of the last five decades have enlarged and fragmented the constituency of social-democratic parties, but has also deeply transformed its ideational core. Combining these empirical findings with the three rival interpretations of the social-democratic project introduced in section one, section three develops three possible scenarios for the evolution of the socialdemocratic project in the near future: decline, drift, and renewal. Section four assesses the likelihood and political meaning of each of the three scenarios for the pursuit of the social-democratic project, also in the light of the recent upsurge of leftwing populism.

\section{Social democracy as an ideational and a mundane project}

Depending on the academic discipline one belongs to, social democracy is categorized and studied in either of two ways. On the one hand, philosophers and political theorists adopt an ideational stance and understand social democracy as an emancipatory project rooted in the Enlightenment and socialist traditions, whose core is usually defined through the concepts of equality and solidarity ${ }^{3}$. On the other, historians and political scientists take a more empirical cue, identifying social democracy using a set of policy programs associated with a family of political parties and social actors or movements that have been active in western countries since the early 20th century, and are rooted in the political experience of 19 th century socialist

\footnotetext{
2 Two recent and paradigmatic examples are Mudge (2018) and Berman and Snegovaya (2019).
}

${ }^{3}$ See, for example, Honneth (2015) and Cohen (2009). 
parties and movements ${ }^{4}$. What philosophers consider to be an exogenous variable, political scientists treat as endogenous, and the reverse. The result is that the dynamic interplay between the ideational and mundane dimensions is lost from sight.

This paper tackles this academic blind spot by proposing that we understand social democracy as a project of social emancipation. Understood as an emancipatory project, social democracy transcends the history of parties and movements to which this label has been applied. It includes, but largely transcends, the destinies of the New Left, third way and other political movements that have dominated the political scene of the last four decades. More broadly, it refers to a view of politics that puts democracy center stage and acknowledges the inescapably social dimension of human life, as against the more individualistic and competitive visions of associated living proposed by capitalism and liberalism ${ }^{5}$. I prefer this to alternative labels such as "socialism", "labour", or simply "left", because throughout the entire post-World War II period this label more than any other has been used to refer to progressive political forces having had governing responsibilities in Western countries. Better than "socialism" or "left", it refers to the successful attempt to combine an ambitious ideational core with an effective mundane program.

Understood as an emancipatory project, social democracy consists of three interwoven dimensions: (1) an ideational account of the good society; (2) a set of mundane political actors and practices, and (3) a social constituency, all three subject to processes of mutual transformation which bring them into constant tension. The ideational core gives the project its emancipatory outlook, that is, the ambition to improve life conditions according to a view that transcends immanent (here and now) perceptions of what is good, whereas mundane politics copes with the tension between the desirable and the feasible, embedding the ideal in concrete practices. The ideational and the mundane dimensions subscribe to different logics. While the ideational mainly proceeds along the discursive lines of an emancipatory narrative whose basis of legitimation is normative, the mundane mainly follows the strategic logic of power competition. These two dimensions are articulated together by a social constituency. At the ideational level, the social constituency defines the audience of the beneficiaries to whom social democracy addresses its emancipatory promise. At the political level, it constitutes the social forces on which the mundane project relies to achieve concrete goals. These two dimensions of the social constituency may not coincide, and their misalignment generates constant strain between the ideational and the mundane levels. The success of social democracy reposes on its capacity to create

\footnotetext{
See, for example, Sassoon (2010); Berman (2006); Wallerstein (2003); Moschonas (2002); Eley (2002); Bartolini (2000), and Merkel et al. (2008).

${ }^{5}$ In a similar vein, Habermas calls it "social democratic reformism" (Habermas, 1986), and Geoff Eley speaks of social democracy: "as the distinctive socialist ideal of democracy" (Eley, 2002, 20). I have provided my own account of this wide view of democracy in Frega, 2019.
} 
temporary equilibria that solve the dilemmas engendered by the tension between its normative and mundane pillars.

According to this model, the success of an emancipatory project depends on three conditions: (1) it must offer a desirable normative account of reality; (2) it must dispose of mundane forces capable of translating the ideal into political action, and (3) it must be capable of mobilizing a sizable social constituency in its support. The three scenarios I outline in section three derive from this model and explain social democracy's crisis in terms of a failure to recreate these conditions under contemporary circumstances.

Using this model, we can single out three conceptions of social democracy. Each roughly corresponds to a historical phase in the evolution of the social-democratic project, although its vitality has generally outlived the historical circumstances of its affirmation $^{6}$. Each of these phases is characterized by a unique combination of different types of ideational core, mundane support, and social constituency. At the institutional level, the social-democratic project is characterized by explicit and systematic reliance on social and political actors (not only the state, but also social partners, social movements, and NGOs) as its mundane counterparts. These two features serve to demarcate it from its direct political competitors. On the one hand, the liberal and neo-liberal contestants, with their near exclusive emphasis on market coordination. On the other , the Christian-democratic alternative, with its emphasis on the family and the Church as major bearers of socio-economic responsibilities (Esping-Andersen, 1990; Hemerijck, 2013).

Phase I. Particularly among authors inscribed in the socialist tradition, it is common to identify the ideational core of social democracy with ideals of economic equality, mainly rooted in the critique of capitalism that animated the first phase of industrialization. Apart from issues of property ownership, the ideational core of this conception focuses on the need to improve workers' material conditions, by reducing working hours, expanding workers' rights, and increasing job stability and salary. During this phase, workers' movements and unions, more than political parties, have provided the strongest mundane support to the project, and industrial workers have played the role of major social constituency. In the beginning, the development of a system of social protection against work-related risks was led by workers' organizations - and sometimes employers, rather than by the state. The model was that of voluntary insurance: workers belonging to the same profession paid a contribution out of their wage in return for social support in the event of a "social risk". During this phase, workers' movements and unions, more than socialist parties, have provided the strongest mundane support to this project, and industrial workers have played the role of the major social constituency. The strike, rather than the electoral campaign, and the plant rather than the public sphere, epitomize the kind of politics typical of this phase (Sassoon, 2010, Ch. 1). Central to this view is a strongly

\footnotetext{
Among others, Sassoon (2010) and Berman (2006) adopt this chronology.
} 
antagonistic conception of society, one rooted in the idea of class. Accordingly, politics is interpreted through the lenses of a mono-dimensional polarization of economic interests along the left-right economic axis, with conservative parties defending the interests of the middle and upper classes, and progressive or socialist or social-democratic parties defending the interests of the lower classes. This view dominated the earlier phase of social democracy's trajectory, and has remained alive for far longer in radical left-wing intellectual political traditions and parties.

Phase II. A second phase began to gain traction in the early decades of the 20th century, once socialist parties seized control of state institutions, finding in them a reliable ally, rather than an enemy, to pursue their goals. The ideational core of this view of social democracy is epitomized by Karl Polanyi's criticism of market commodification (Polanyi, 1944), and by Thomas Marshall's idea that, besides civil and political rights, social rights are a third, equally necessary, presupposition of citizenship (Marshall, 2009). The idea of social rights opens up the question of the overall quality of life of the popular classes, thus enlarging the social constituency beyond workers to their families, the unemployed, the young, and the elderly. At the mundane level, the idea of a robust welfare state with great distributive capacity emerges as the specific achievement of social democracy. At the same time, class conflict is progressively replaced by the idea that the interests of capital and labor can be reconciled. Variance among welfare state regimes notwithstanding (EspingAndersen, 1990), a common framework emerged throughout Europe, based on the idea of a political community protected by institutional guarantees, where capital and labor cooperate together, and where redistributive mechanisms cater for citizens needs, while providing capital with a trained and less conflictual workforce. This interpretation had maximum currency between the end of World War II and the late-1970s, although its success in southern European countries peaked two decades later.

Phase III. A further major transformation of the social-democratic project emerged in the late-1960s, when new social movements begin to challenge structures of social domination that the welfare state had not tackled ${ }^{7}$. This move further expands the scope of emancipation to other dimensions of human life beyond work and social protection, as well as to other social constituencies. At the ideational level, this new version reconnects more directly with emancipatory views laid out in the Enlightenment project. It understands the social-democratic project in universalistic terms, as an open-ended process of social, cultural, political, and economic emancipation from domination and exploitation, whose subject is humanity in its entirety (Wagner, 2016). This new version emerges out of awareness that progress achieved in the previous decades had not benefited all in the same way, and that many forms of formal and informal injustice - mainly of a non-economic kind -- remained

\footnotetext{
${ }^{7}$ In an extremely vast literature on the anti-authoritarian meaning of these movements and their disconnection from mainstream left-wing politics, see Eley (2002); Sassoon (2010), and Polletta (2012).
} 
so far unaddressed. The transition toward the third phase has to be understood in two distinct but complementary senses. On the one hand, the emergence of new social risks made it plain that in the changed circumstances of the post-industrial society the traditional welfare state left the needs of social groups such as the unskilled, the young, and women largely unmet (Armingeon and Bonoli, 2007). On the other hand, a new wave of social movements showed the extent to which western society had failed to tackle forms of domination not directly related to the economic sphere but inscribed in gender, race, and age relations within western countries, as well as in patterns of colonial exploitation. Norms relating to gender and racial equality, environmental protection, concern for future generations, and global justice that were present in fragmentary form in utopian socialism but then largely forgotten by mainstream left-wing movements ${ }^{8}$ took center stage in the normative core of the social-democratic project. Both these transformations have been expedient in opening the social constituency of social democracy to other social groups, and particularly to the new middle classes, thus transforming in depth the very identity of the project. At the mundane level, new-left parties sidelined traditional socialdemocratic parties as the bearers of the new version of the social-democratic project. The Third Way political program (Giddens, 1998), combined with its social policy counterpoint of Social Investment Welfare State (Hemerijck, 2017), provided its typical mundane instantiation in a self-conscious attempt to renew the socialdemocratic project under deeply changed social, cultural, economic, and technological conditions. This interpretation of the third phase of the socialdemocratic project diverged sharply from more standard accounts which interpret the third phase in economic terms, equating the third way and the new left with a neoliberal drift. In subsequent sections I explain why such an account, by reducing the social-democratic project to its economic dimension, and by reducing its normative core to the value of equality, fails to understand the logic of its successive transformations.

Scholars have usually seen in egalitarianism and solidarity the two normative principles animating the social-democratic project (Stjernø, 2009; Huo, 2009; Mudge, 2018). My account adds to these a universalistic orientation. Indeed, more than the concern for economic equality ${ }^{10}$, it is the expansive (universalizing) inclusionary drive that is essential for the identification of a social-democratic emancipatory project. It is this universalizing aspiration that allows us to distinguish

\footnotetext{
8 "Utopian socialism proved a moment of exceptional radicalism on the gender front, which remained unrecuperated until the late twentieth century" (Eley, 2002, 30). As (Audier, 2017) has recently shown, the same holds for environmentalism.

${ }^{9}$ Paradigmatic accounts include Crouch (2004) and Streeck (2014). For a recent statement and a broad historical account, see Mudge (2018).

${ }^{10}$ Economic redistribution through the welfare state has, indeed, been also largely supported by conservative and Christian-democratic parties, and is today openly supported by right-wing populist parties.
} 
the social-democratic project from other political cultures, whose views of emancipation betray an exclusionary basis, usually defined on ethnic or religious grounds. The normative pull of universalism, implicit since the beginning of the project, has become fully explicit only in its third phase. Table Error! Reference source not found. recapitulates the features of these three conceptions:

Table 1. Social-democracy's three phases

\begin{tabular}{|l|l|l|l|}
\hline & Till WWII & WWII to mid-70s & Mid-70 to today \\
\hline Normative core & Economic equality & Social inclusion through & $\begin{array}{l}\text { Anti-authoritarianism, } \\
\text { environmentalism, } \\
\text { pacifism. }\end{array}$ \\
\hline Mundane support & Workers' unions & Social-democratic parties & $\begin{array}{l}\text { New Left parties and social } \\
\text { movements }\end{array}$ \\
\hline $\begin{array}{l}\text { Major social } \\
\text { constituency }\end{array}$ & Industrial workers & Working class & New middle class \\
\hline Area of improvement & Working conditions & $\begin{array}{l}\text { Health, education, } \\
\text { housing }\end{array}$ & $\begin{array}{l}\text { New social risks, non- } \\
\text { economic discrimination }\end{array}$ \\
\hline
\end{tabular}

It is important to bear in mind that these three versions of social democracy are not alternative accounts but, rather, historically successive variants of the same emancipatory project. What, then, gives this project its historical unity if everything changes - the normative core, the mundane counterpart, the social constituency? My hypothesis is that we can see the three phases as a process of progressive enlargement of the audience of addressees of the emancipatory project: its common thread is a vision of the good society whose content is expanded once the means to achieve new goals become available, and once new groups support it. In the course of its history, new social demands emerge which claim universal validity but which are rooted in the historical experience of specific social groups. While this process did not unfold in a unified chronology, the trend has been common to all Western countries (Manow et al., 2018; Eley, 2002; Bartolini, 2000).

Enlargement of the scope and audience of the social-democratic project has tremendous political implications, as it alters the conditions under which its normative and mundane pillars are articulated via different social constituencies. Indeed, what to many has appeared to be a process of linear expansion driven by the idea of progress is indeed characterized by deep discontinuities which create tensions, and cleavages, between social groups that have all come to be considered legitimate addressees of social-democratic parties, but whose interests as well as values happen to diverge, and even to conflict, thus threatening not only the mundane chances of 
social-democratic parties but, more dramatically, the feasibility of its entire emancipatory project. Understanding the nature of these tensions will prove vital to address the question of what political action should be taken by mundane actors wishing to advance this emancipatory project. To do this, in the next section I discuss the three main lines of cleavage across which today's social-democratic constituency is internally split.

\section{Social-democratic dilemmas}

Struck by the scale of the present crisis among social-democratic parties, we tend to forget that working class disaffection with social democracy is as old as social democracy itself. It is noteworthy that in the Scandinavian countries, where a robust welfare state exists since the late-1950s, this phenomenon had already begun to gain traction in the early-1960s $\mathrm{s}^{11}$. It has also been shown that around the early-1990s the process of electoral substitution was almost complete in all European countries: a significant share of a declining working class voted for right-wing parties, and support for social-democratic parties mainly came from the new middle classes (Gingrich and Häusermann, 2015; Oesch and Rennwald, 2018).

Seen from the vantage point of this broader historical perspective, the idea that social democracy enjoyed prolonged success thanks to the massive support of the working class, tarnished only in recent years as a result of disruptive events such as the financial and then refugee crisis, is unwarranted. Drawing on empirical literature, in this section I identify and examine the challenge the social-democratic project faces in the context of globalized, post-industrial societies and reconnect it with the tension between its emancipatory normative core and its mundane political project. The challenge is described in terms of three dilemmas that beset the social-democratic project owing to conflicting interests among groups belonging to its social constituency. These conflicts, in turn, call into question the very content of the normative core of the social-democratic project ${ }^{12}$.

In this paper I focus only on the challenges that threaten social democracy as a project of emancipation. From this perspective, the three major challenges are economic, cultural, and political. This tripartite model differentiates itself from the

"See Evans (2017); Przeworski (1986), and Häusermann (2010).

${ }^{12}$ The salience of these three dilemmas varies across countries, as literature on welfare democracies has begun to show. For empirical data in comparative perspective, see Manow et al. (2018) and Beramendi et al. (2015). We should also bear in mind that these dilemmas do not coincide with the concrete challenges faced by its mundane counterpart, since parties have also to deal with contingent constraints which may have no direct relation to the ideational core, such as technological change, demographic cycles, fluctuations in the economy, exogenous shocks, and party structure and dynamics. 
mainstream tendency to conceptualize the political space in bi-dimensional terms ${ }^{13}$. As I argue below, there are analytic as well as political reasons that explain why we should differentiate the cultural from the political dimension and why, as a consequence, the juxtaposition of economic and cultural factors, while significantly improving on the unidimensional left-right conceptualization, remains incomplete. If each of these dilemmas already represents a considerable challenge to the socialdemocratic project, their combined effect seriously jeopardizes its survival . In describing these dilemmas, I take for granted the results of previous research that has proved beyond reasonable doubt that the electoral opening toward the middle classes has been an inescapable electoral necessity since the very beginning of the electoral history of social-democratic parties (Benedetto, Hix, and Mastrococco, 2020). Even in the absence of the daunting challenges that emerged later, social-democratic parties are structurally compelled to seek the electoral consensus of the middle class. This, in turn, compromises their class-based identity, inviting the risk that working class voters will endorse alternative (non class-based) allegiances and abandon socialdemocratic parties. This dilemma has generally been examined in electoral terms as the mundane trajectory of social democracy (Przeworski, 1986). In this section I contend that, in addition to its mundane implications, normative reasons too have prompted and then legitimated the move to the center, a point that has been insufficiently stressed. To that extent, the alliance between the middle class and the mundane social-democratic forces has been the inevitable result of the inner transformation of the ideational core of the social-democratic project itself, and not the mere result of a pragmatic strategy for seeking electoral success.

\subsection{The economic dilemma}

Since its inception, but with increased momentum after World War II, the welfare state has become the privileged instrument for the achievement of the emancipatory goals of social democracy. Disadvantaged social groups have sought to obtain economic and social protection from the state, while social-democratic parties that identified with this project have struggled to obtain a social constituency large enough to sustain its financial costs. These are two sides of the same coin. Enlargement of a social-democratic base required to finance the welfare state has brought with it new claims and new pressures, since the social groups newly coopted to grant its survival bore needs, interests, values, and expectations that partly diverge from those of the

\footnotetext{
${ }^{13}$ There are exceptions, however. Kitschelt and Rehm (2014) differentiate the authoritarian dimension from the economic and the cultural, although the "greed, grid, group" model does not exactly overlap with mine. Another threefold classificatory model that overlaps to a degree with mine is that developed by Pippa Norris and Ronald Inglehart (Norris and Inglehart, 2019), who propose to position parties into a three-dimensional space defined by three axes: left-right; libertarian-authoritarian, and populistpluralist.
} 
working class. These new needs reflected specific disadvantages whose acknowledgment required the enlargement of its ideational core. Pursuit of the socialdemocratic project assumed and reposed on the possibility that the claims of this enlarged and diversified base could be accommodated within the confines of a generous welfare state. Yet in the course of this process social-democratic parties have been caught in an economic dilemma whose implications are at the same time mundane and ideational.

Given the importance of the welfare state in the advancement of the socialdemocratic project, comparative welfare state economics provides a privileged perspective to understand how the ideational and mundane dimensions of the socialdemocratic project have evolved. Two empirical perspectives appear relevant. The first focuses on how social-democratic parties have catered for the expectations and needs of the diverse components of the working class, rather than of the working class as an undifferentiated whole. Official rhetoric notwithstanding, it has been shown that in the course of their history social-democratic parties have not supported the working class in unqualified terms, but have systematically catered for the needs of a specific sub-group of privileged workers for which they have secured stable and comparatively well-paid jobs. Beyond this group of protected insiders, economic outsiders have enjoyed much worse economic conditions, mainly characterized by precarious and part-time jobs and unemployment (Rueda, 2007; Emmenegger et al., 2012). The welfare state, often with the support of social democracy's mundane counterparts (parties, trade unions) has systematically been tilted toward the needs of insiders, for example, by privileging job protection over active and passive policies, whose beneficiaries would have been the unemployed and the underemployed. Moreover, this solid core of insiders has been disproportionately male, white and national, thus adding a second layer of gender and race discrimination to the first layer of economic discrimination. This trend is neither minor nor recent, having characterized the majority of western countries since at least World War II, in many cases even earlier, often with the support of trade unions ${ }^{14}$. Outsiders have functioned to insulate insiders from the risk of unemployment by acting as a buffer (hired in good times and fired in downturns) bearing the brunt of fluctuations in the business cycle.

The second perspective focuses on the social consequences of the transition to a post-industrial society, identifying new social risks which have emerged in the last three decades (Armingeon and Bonoli, 2007; Beramendi et al., 2015; Hemerijck, 2013). Here the focus is not on social dynamics that are internal to the working class, but on expansive trends that have broadened the audience of welfare policies to outsider groups such as the young unemployed, women, and unskilled, often immigrant, workers. As these studies show, post-industrial society is characterized not

"See Cowie (2010), Häusermann (2010), and Sassoon (2010) for empiricl evidence and Rueda (2007) for theoretical modelling. 
only by new occupational profiles, but also by a greater degree of social fragmentation, and by the decline of the traditional model of the nuclear family. In this context, a socio-economic model based on a single wage-earner - usually male -- has proven increasingly incapable of fulfilling the needs of a more complex and fragmented society and, as a consequence, a welfare state centered around income maintenance through social insurance and job protection has proven to be increasingly inadequate to fulfill its own normative goals. As a consequence of this socio-economic transformation, "European societies are confronted with a range of 'new social risks', varying from rising old age dependency, unemployment hysteresis of low-skilled and older workers, insufficient social security coverage, precarious employment, human capital depletion also due to rapid technological change, retraining needs, youth and long-term unemployment, increasing levels of early school drop-out, greater family instability and single parenthood, and unsatisfactory work-care-family reconciliation, especially for working mothers" (Hemerijck, 2013, 60).

Bearers of these new social risks are not necessarily outsiders in the previous sense, although many certainly are. Others hold jobs that may be precarious yet wellpaid, socially prestigious, and culturally enriching. However, like outsiders, to secure their position within the job market these categories need to be supported with specific social policies such as child-care services, access to higher education and continuous training, and active labor market policies that compensate for the flexibility of labor markets. Like outsiders, they too make claims on the welfare state that, however, conflict with insiders demands for employment protection. On the one hand, policies that increase employment protection insulate insiders from the risk of unemployment but reduce outsiders' job opportunities . On the other , active and passive policies required to protect outsiders from occupational insecurity result in higher taxes and lower wages that in turn threaten insiders' jobs (Rueda, 2007). Moreover, as the debate about social investment has shown (Hemerijck, 2017), diverse types of social policy end up benefiting different social groups, pitting issues of fairness at cross purposes with issues of efficiency.

The major upshot of this transformation is that de-commodification, the traditional rock-solid policy of first-stage social-democracy (Polanyi, 1944; EspingAndersen, 1990), does not provide adequate answers to the needs of these new social groups, which may well find better chances of personal improvement in new patterns of progressive re-commodification. Social-democratic parties are thus caught in an economic dilemma, aggravated by gender and race patterns of discrimination. At the mundane level, they have to decide which constituency's interests they will defend, given that under budget constraints the resources are usually insufficient to satisfy all demands. This turns out to be a decisive issue, since conservative governments may be able to pursue policies that are more attractive to outsiders than those promoted by social democrats if these decide to side with their historical constituency. For example, outsiders share with upscale groups an aversion to policies that promote higher levels of insider job protection in the decommodifying tradition (Lindvall and 
Rueda, 2014). But at the ideational level the challenge is even more daunting, since it calls into question the egalitarian implications of social-democratic politics. Indeed, if one admits that the social and economic benefits enjoyed by insiders have been paid for by outsiders, then a problem of justice arises: should we protect insiders' established rights at any cost as social democratic parties and trade unions have generally contended, under the assumption that extension of their rights to all workers is a non-negotiable priority, even in the face of clearly unlikely chances of realization? Or should we, instead, seek to equalize conditions and distribute risks and benefits across social groups?

The paradox is genuine, since balancing these injustices would require renouncing one of the most deep seated normative intutions of the social-democratic project, that is full employment. At the mundane level, catering for the needs of outsiders and bearers of new social risks could also, as indeed it has happened, trigger the resentment of working-class insiders, thus disparaging social-democratic electoral strategies. The dilemma between de-commodification and re-commodification evoked above exemplifies well this deep entrenchment of normative and mundane issues, pointing to its deep rooting within contemporary social structure.

\subsection{The cultural dilemma}

If the first dilemma emerged out of conflicting material interests determined by the expansion of social democracy's constituency, the second arises from the broader socio-cultural transformation of post-industrial societies. In the last four decades, processes of feminization, tertiarization, educational upgrading, and the spread of non-standard jobs (Oesch, 2006) have deeply transformed the sociological and cultural identity of the working class. This trend is reinforced by the fact that in the post-industrial economy the nature and content of many new jobs often require and emphasize attitudes of autonomy, tend to be based on interactions with other persons rather than with objects, privileges horizontal over vertical integration, and have a higher symbolic content than traditional industrial jobs. Work identity has thus begun to be diffracted, with these differences in working experiences determining varying attitudes toward life but also toward political preferences (Kitschelt and Rehm, 2014). The upshot of this occupational revolution has been a deep transformation in the value preferences of an increasingly large strata of workers, for which individuality and creativity have replaced stability and conformity as the central values of professional identity (Florida, 2014). Even though they occupied only a marginal position in the ideational core of the first and second phases of the social-democratic project (see above), these values are nevertheless solidly inscribed in the ideational core of the Enlightenment tradition, and for this reason their incorporation in the normative core of the social-democratic project has been rapid and persistent, thanks also to their broad diffusion in the new middle classes. One of the major implications of this sociological transformation is that: "the educated middle classes, particularly 
in interpersonal service sector occupations (Kitschelt, 1994), have become the main progressive force in European politics" (Gingrich and Häusermann, 2015, 53). At the same time, increasing swaths of working class voters have embraced anti-modern values that find better political expression in the cultural conservatism of right-wing parties (Bornschier and Kriesi, 2012). While at the normative level personal autonomy, environmentalism, cosmopolitanism, and pluralism had been at the heart of the social-democratic project since its beginnings, it is only through incorporation of the new middle class into its social constituency that they have acquired the political momentum necessary to enter the political agenda. Taken together, these two trends have determined the progressive marginalization of traditional working class values within the normative core of the social-democratic project (Williams, 2017; Goodhart, 2017; Gest, 2016).

The result is the rise of a new cultural cleavage that cuts deeply into the socialdemocratic constituency, and that has alternately been labeled in terms of postmaterialist vs. materialist values (Inglehart and Welzel, 2005), anywhere vs. nowhere (Goodhart, 2017), cosmopolitans vs. communitarians (Zürn and de Wilde, 2016), brahmin left vs. merchant right (Piketty, 2020), libertarians vs. authoritarians (Norris and Inglehart, 2019), winners vs. losers of globalization (Kriesi et al., 2008), GAL vs TAN (Hooghe and Marks, 2018), or universalism vs. particularism (Bornschier, 2010). Dividing lines concern not only value orientations as contended by theorists of identity politics. More deeply, they affect key social-democratic policy issues such as European integration, immigration, environment, tertiary education, and globalization. This cultural cleavage is sociologically rooted, as post-materialist, liberal, cosmopolitan values are disproportionately more widespread among members of the new urban middle class, which confirms itself as the class which best embodies a central set of values lying at the heart of the normative project of social democracy ${ }^{1.5}$.

The political implications of this new cleavage can be stated in terms of a cultural dilemma in which the ideational and mundane dimensions are inextricably entwined. Social-democratic parties must decide whether to remain faithful to the value preferences of its historical working class constituency, thus reneging on the most updated version of its normative core, or whether to endorse a more universalistic and inclusive set of values, thus shifting allegiance to the new middle class, exposing themselves to the criticism of neo-liberal drift ${ }^{16}$.

${ }_{15}$ Bornschier (2010) and Kriesi et al. (2008) establish a causal correlation between occupational and educational level on the one hand and cultural positioning on the other. Occupation and education are taken to be a reliable proxy of social class. For theoretical explanations and empirical evidence of the disproportionate representation of working class members in extreme right parties, see Rydgren (2012); Mayer (2014), and Spies (2013).

${ }^{16}$ For empirical evidence in US and UK, see Gest (2016) and Hochschild (2016) and Coe (2018) for a vivid literary rendering of the same ideas. 
At a time when social-democratic parties are severely criticized for their economic move to the center, left-wing critics do not seem to be equally attentive to the political meaning of working classes' shifting allegiances to parties willing to support their value preferences. Indeed, the rise of right-wing populist parties has been heavily depedent on these parties' willingness to exploit value preferences that social-democratic parties see as incompatible with their normative project. But at the same time, the rise of new left movements and parties, often of a populist mould, rejecting the European project or calling for more restrictive immigration policies ${ }^{17}$ shows the extent to which this dilemma is deeply entrenched in today's social-democratic project.

\subsection{The political dilemma}

Social-democratic parties today face a third dilemma which is more directly political, as it concerns the nature of legitimate political authority and the forms it takes. This dilemma is somehow more difficult to identify than the previous two, since the literature tends to conflate it with the cultural dilemma. We have, however, solid theoretical reasons to analytically distinguish the cultural conservatism highlighted by the cultural dilemma from the political authoritarianism which lies at the heart of the political dilemma (Stenner, 2005; Hetherington and Weiler, 2009; Duckitt et al., 2010). Indeed, whereas the cultural dilemma can be mainly described in the exclusionary terms of nativism, nationalism, and provincialism, the political dilemma emphasizes the anti-establishment and anti-democratic factors which qualify authoritarianism as a conception of social order and political authority. As a conception of politics, authoritarianism bears a distinctive threat to constitutional democracy, endangering major achievements such as the rule of law, pluralism, the separation of powers, and respect for knowledge-based forms of authority. Two perspectives may help us understand its implications for the fate of the socialdemocratic project. The first emphasizes the tensions between libertarian and authoritarian attitudes, whereas the second focuses on the historical tension between revolution and reform. Both distinctions, far from overlapping with the left-right cleavage as many contend, cut deeply into the social-democratic political camp.

Political scientists and psychologists have long contended that authoritarianism is not the exclusive prerogative of the right ${ }^{18}$. Left-authoritarianism identifies a class of voters that are politically aligned with social-democratic parties on economic issues, that have traditionally voted for left-wing parties, but which display authoritarian orientations that are deeply at odds with the ideational core of the social-democratic

\footnotetext{
${ }^{17}$ This has been the case of Syriza in its first phase, of Corbyin's Labour during the Brexit campaign, and of La France Insoumise and Movimento Cinque Stelle in a more continuous and sustained way. I come back to the implications of this trend for the social-democratic project in the next section.

${ }^{18}$ Classical references include Lipset (1959); Shils (1954), and Ray (1974). For a more recent appraisal of this phenomenon, see Federico et al. (2017); De Regt et al. (2011); Marx and Schumacher (2018); Lefkofridi et al. (2014), Flanagan and Lee (2003), and Thomassen (2012).
} 
project, and in particular with its most recent anti-authoritarian trend ${ }^{19}$. Leftauthoritarians "stress hierarchic authority and find security in the order it provides, whereas libertarians stress autonomy" (Flanagan and Lee, 2003, 257). Authoritarians tend to be more impatient with the legal protections and constitutional intricacies of constitutional democracy, and less exacting in terms of forms of political participation and inclusion. "From their initial designation as 'pre-Fascist' personalities (Adorno et al. 1950) through to the present, authoritarians have been understood as individuals who possess a rather tenuous commitment to democratic processes, and who are extremely uncomfortable with, even uncomprehending of, the core components of a democratic system" (Stenner, 2005, 250). Considering the central role democracy and democratization have played in the entire history of the social-democratic project, as well as the increasing role anti-authoritarianism plays in its present stage, it seems obvious that left-authoritarians' political preferences are deeply at odds with the ideational core of the social-democratic project. Yet it is estimated that leftauthoritarians account for some $15-20 \%$ of the traditional left-wing electorate in Europe (Lefkofridi et al., 2014, 72) ${ }^{20}$. Left-authoritarianism poses a challenge of its own to the social-democratic project. At the ideational level, social-democratic parties have to face the fact that a solid block of their historical constituency undervalue a central tenet of their emancipatory project. At the mundane level, they have to face the fact that populist parties - both left and right leaning -- exploit the authoritarian tendencies of left-wing voters to draw them into their camp (Norris and Inglehart, 2019; Morgan, 2018; Afonso and Rennwald, 2017; Spies, 2013; Thomassen, 2012; Hetherington and Weiler, 2009).

The second distinction is that between revolution and reform. As we know, this distinction has riddled the political left for most of its life, often severely hampering its chances of winning electoral majorities (Bartolini, 2000). Since the end of World War II, however, in most western countries the revolutionary and reformist attitudes have more or less successfully joined forces under the lead of the reformist prong: with few exceptions, radical left-wing parties have attracted and tamed the most disruptive aspirations of the left-wing electorate, often putting them at the service of the social-democratic project by serving as junior partners in center-left majorities. Today this anti-system attitude, which in the interwar period severely disrupted the social-democratic project, resurfaces under the guise of right-wing and left-wing populism ${ }^{21}$. While alien to the violent overtones of left-wing revolutionary radicalism,

${ }^{19}$ Left-authoritarians: "are citizens who blend left-wing economic with traditional/authoritarian sociocultural views” (Lefkofridi et al., 2014, 66). See also De Regt et al. (2011); Federico et al. (2017); Marx and Schumacher (2018), and Stenner (2005).

${ }^{20}$ For example, it is estimated that they constituted a significant share of Barack Obama and Hillary Clinton supporters during the last two presidential campaigns (Hetherington and Weiler, 2009, 6).

${ }^{21}$ See Norris and Inglehart (2019) and Judis (2016) for an account of populism as a logic of political action with redemptive overtones, as opposed to the reformist and "reasonable" way of proceeding 
the populist surge nevertheless contains a real threat, since what is at stake in the divide between populism and anti-populism are radically different conceptions of political legitimacy (Moffitt, 2018; Müller, 2016). On the one hand, these parties exacerbate anti-systemic stances and de-legitimate institutions of political mediation that are at the heart of the social-democratic understanding of legitimate politics. On the other, by casting social-democratic and conservative parties on the same side of a new political cleavage which pits the people against elites and the system, they dispossess social democracy of the role of legitimate bearer of the emancipatory project, one that must uncompromisingly side with "the people".

These two perspectives highlight tendencies to acquiesce in (if not clearly favor) non-democratic patterns of political authority that are immanent in the left-wing electorate, and that some left-wing populist parties are already exploiting. In this way, a third social-democratic dilemma emerges between a constituency that is solidly committed to the democratic values that lies at the core of the social-democratic project, and one that is ready to waive them in exchange for material or cultural goods it considers more valuable.

As a consequence of the transformations evoked in this section, the socialdemocratic constituency is fractured along economic, cultural, and political lines which give rise to a plurality of sub-constituencies whose political preferences are deeply at odds. These sub-constituencies have diverging interests which end up with conflicting political demands being made on the welfare state, disagree about the social norms that should orient social life, and endorse rival conceptions of the legitimate form of political authority. These cleavages challenge the very project of social democracy not only at the level of its central mundane achievement - the welfare state - but also, and more dramatically, at its ideational core. Unsurprisingly, this situation has exposed social-democratic parties to challenges from conservative as well as populist parties. Conservative parties have found it rewarding to promote policies that serve the interests of outsiders, as these side with upper-scale classes in contrasting policies that favor job protection (Lindvall and Rueda, 2014). Right-wing populist parties have exploited the cultural backwardness of insiders, appealing to their sense of social decline through policies targeted against internal or external foes (Goodhart, 2017), while left-wing populist parties promise to reconcile socialdemocratic demands with the striving for a more redemptive kind of politics (Arditi, 2005).

typical of social-democratic political parties. See Cohen (2019); Frega (2020); de la Torre (2019) for a discussion of the theoretical incompatibilities between social-democracy and left-wing populism. 


\section{Three scenarios}

In this reconstruction I have assumed that social democracy identifies a normative project, borne by a social constituency, with the mundane support of a family of political parties. I have also contended that an emancipatory project can be viable only under the condition that these ingredients are all present and well integrated. In the course of its history, the normative content of social democracy was first enlarged and then transformed, and its social constituency has progressively evolved too, acquiring fresh recruits from the new middle class, while losing part of its footing in its original working class constituency. If we admit that a degree of overlap among a normative core, a social constituency, and a set of political actors is required to empower social democracy as an emancipatory project, three alternative plots seem to be the most likely, which I call the "decline", the "drift", and the "renewal" of the social-democratic project. Each scenario is built starting from a different interpretation of the political meaning of the three dilemmas identified in the previous section. I will briefly discuss each in turn, leaving to the next section the task of examining their implications for the social-democratic project.

1. The decline of social democracy. The first scenario assumes that the three dilemmas describe deep fractures that cannot be overcome. This diagnosis implies that the social-democratic emancipatory project, based as it is on the possibility of their resolution, has reached its end point. Social democracy would then have completed its historical cycle, in the same manner in which liberalism, once the normative motor of European social emancipation, ran out of steam, finding itself incapable of tackling the new challenges of industrial society and to provide convincing answers to new social needs and expectations, thus giving way to socialism and social democracy as new emancipatory projects. Indeed, many scholars contend that the social-democratic project was so inextricably tied to the social struggles and material conditions of industrial society that in post-industrial times its role has become either impossible or superfluous ${ }^{22}$. One would then have to acknowledge that, with the closing of the industrial cycle, the social-democratic project has also come to an end, many of its core values having become an acquis of western political culture, its main goals having significantly been achieved but its constituent traits making it unsuited to tackle today's political challenges, for which it was not designed. If this scenario is plausible, rather than investing further energies in unlikely efforts to resuscitate the social-democratic project, we had better devote our time to the search for a new social constituency, and to the construction of a new normative project capable of reinventing the emancipatory project of modernity, once set in motion by liberalism and pursued by socialism and social democracy till they too were exhausted. And if this new project can fairly be termed left-wing populism, as many have contended, we have to be extremely clear that such a project will be at

${ }^{22}$ See Crouch (2004); Streeck; (2014); Lavelle (2008), and Bartolini (2000). 
odds with some central tenets of the social-democratic project as we have come to know it (Frega 2020; Cohen 2019; La Torre 2019).

2. The drift of social democracy. This scenario is based on the assumption that economy continues to provide the dominant key to politics, so that the second and third dilemmas have only minor relevance and can, therefore, be discarded ${ }^{23}$. According to this view, the negative electoral results experienced by social-democratic parties in the last decade are mainly attributable to their abandonment of pro-work, redistributive, de-commodifying policies as they had been developed and canonized during the consolidation phase of the Thirty Glorious era. Supporters of this scenario contend that the social-democratic decline bears entirely on the neo-liberal economic drift promoted by new-left and Third Way parties and see the chances of its renewal in the dismissal of the cultural politics of the 1990s and the steady return to the decommodifying, materialist, and distributive politics of the previous era ${ }^{24}$.

3. The renewal of social democracy. A third scenario assumes that the three dilemmas are real, but can be tackled and overcome. Contrary to the second scenario, renewal acknowledges the multi-dimensional nature of the present crisis, and contrary to the first scenario it contends that it is not irreversible, since it is the product of the contingent misalignment of social democracy's ideational core, mundane pillar, and social constitution. It assumes, in other words, that the socialdemocratic project may be entering a fourth phase, one that would reshape once again the contours of the social-democratic emancipatory project. As in the past, the transition to a new phase requires unprecedented strategies to preserve and enlarge the normative core via the support of new mundane actors and the transformation of its social constituency. New mundane actors such as Green parties, transnational NGOs, new social movements and other more liquid forms of collective action as we begin to see appearing may replace Third Way and new-left parties, and a new social constituency may emerge from the ashes of the now evaporated alliance between traditional working classes and new middle classes. Speaking of a fourth phase implies that the social-democratic project will have to undergo a Hegelian process of Aufhebung, capable to preserve its own identity while deeply transform it. It will have, therefore, to proceed through an expansive move whose contours are yet to be devised.

${ }^{23}$ See Berman and Snegovaya (2019) and Mudge (2018).

${ }^{24}$ This was already the idea behind Nancy Fraser's call for a return from recognition-based to redistribution-based policies (Fraser and Honneth, 2003). But see Fraser (2013) for a partial revision. See also Mouffe (2005) for defense of the primacy of the economic dimension. For an early and prescient criticism, see Habermas (1989). See Crouch (2018) for a later re-appraisal. 


\section{Implications for policy and politics}

Let us now briefly examine some political implications of these three scenarios for the future of the social-democratic project.

If the first scenario is true, then the social-democratic project as we know it will have only modest chances to be further pursued. Social-democratic parties will likely undergo the same fate suffered by liberal forces in Europe nearly a century ago: they will have to settle for a smaller social constituency, likely that of the new middle class that more strongly supports its normative core. The social-democratic project will be replaced by a new emancipatory project that may turn out to be as different from the social-democratic as the social-democratic differed from the liberal project. One possibility is that the neo-liberal form of social organization will become hegemonic, with increasingly lower levels of social solidarity, progressive dismantling of the welfare state, and an increasingly commodified social life. In another scenario, rightwing populist parties will take over welfare politics, limiting, however, its benefits to nationals, strengthening anti-immigration policies within a framework of welfare chauvinism, as is already occurring in some North-Western European countries. A third option is that left-wing populists take the lead. Unencumbered by socialdemocracy's heavy ideological legacy, and freer to re-aggregate social forces and social interests along new lines, populist parties will not have to face the burden of the threefold social-democratic dilemma. At the normative level, however, populist projects, even left-wing ones, will only partially recover the normative core of social democracy, as this would in any case be possible only by facing and solving the three social-democratic dilemmas, which populists need to ignore if they wish to seize power. As evidence has begun to show, they will partially or substantially reject the cosmopolitan dimension of the social-democratic project, reclaiming the renationalization of the solidary community, the retrenchment of forms of international cooperation, and the break-up of the European project ${ }^{25}$.

One may assume that this new project will put less emphasis on the emancipatory value of democracy, perhaps relegated to the role of an elitist ideal, and much more emphasis on communitarian and nationalistic values. Welfare solidarity, Europeanism, pacifism, environmentalism, social inclusion, and pluralism are not likely to be part of its ideational core. More dramatically still, the institutional features of constitutional democracy as we know them will be at risk, as populism conveys "a particular authoritarian understanding of how democratic politics and government should function" (Finchelstein and Urbinati, 2018, 22) which is deeply at odds with the values embedded in the social-democratic normative project. These and similar moves will be necessary to overcome the political impasses produced by the three social-democratic dilemmas, and to promote the creation of a new social constituency. Social democrats may be as disappointed by this evolution as traditional

${ }^{25}$ For empirical evidence, see Manow et al. (2018) and Judis (2016). 
liberals had been in the face of the rise of socialist mass movements. Yet from the standpoint of tomorrow's new values, this move may turn out to become not only the winning political strategy, but also the seed of a new interpretation of the emancipatory project, one that reverses some trends, and opens up opportunities to improve the lives of social groups that are today's losers. As Antonio Gramsci famously wrote: "the crisis consists precisely in the fact that the old is dying and that the new cannot be born. In this interregnum the most varied morbid symptoms appear". From the standpoint of the social-democratic emancipatory project, however, this solution cannot but appear as a form of moral and political regress, as it rejects a significant part of its normative core.

According to the second scenario, a modestly radicalized version of politics as usual seems the way to go. This scenario is built on the idea that today's political space can still be described in the unidimensional terms of the left-right economic cleavage. This scenario, therefore, considers only the economic dilemma, and more redistributive and anti-austerity policies will be invoked to solve it, whereas the other two dilemmas will remain largely ignored or denied. To recover from their electoral losses, supporters of this scenario contend, social-democratic parties would simply have to move back to the first-phase conception of the social-democratic project, reintroduce class-based policies, re-center the welfare-state on its original decommodifying idea, and stop austerity programs, looking for support in radical leftwing parties and social movements. However, if the analyses proposed in the second section of this paper are warranted, it is highly implausible that a renewed socialdemocratic project centered simply around this program will be successful. Indeed, as empirical evidence shows convincingly, members of the working class vote for right-wing parties mostly for cultural and political, and not for economic reasons ${ }^{26}$.

On the mundane level, supporters of the second scenario fail to acknowledge that the opening toward the center was not motivated merely by electoral reasons, but rather by the socio-demographic consequences of the transition to the post-industrial society which then engendered the cultural dilemma. On the ideational level, they overlook the fact that the new middle class has become social democracy's most enthusiastic source of support because its cultural and political values are much closer than working class values to its ideational core. If this is granted, the disruptive effects of the second and third dilemmas will continue to erode the social-democratic constituency even in the unlikely case that the economic dilemma can be tackled and solved without addressing the other two. Hence the combined effect of the three dilemmas described above speaks against the viability of this nostalgic longing for the lost past of Keynesian happiness which could, at best, help social-democratic parties

${ }^{26}$ See, for example, Bornschier and Kriesi, 2012 which explicitly quote anti-universalism and, to a lesser extent, distrust of democracy as the most important factors to explain right-wing vote among members of the working class. With reference to the US and UK, Gest 2016 contends that the best predictors of working class vote for extreme-right parties are social and political, and not economic, deprivation. 
draw into their camp a share of disaffected non-voters from the lowest economic strata. The recent failure of Jeremy Corbyn's and Bernie Sanders' projects can be seen as a partial confirmation of this. At the mundane level, this scenario leads to a situation that is structurally unstable, and we have to expect that sooner or later it will drift either toward the first or the third.

If the third scenario is true, the social-democratic project can be relaunched under the stringent conditions of accomplishing another expansive move, by enlarging the audience to which its message is addressed so as to encompass forms of exploitation and injustice still unmet, no matter whether within or beyond the domestic borders of national politics. This move would take the social-democratic emancipatory project into its fourth phase. Such an expansive move would follow the same logic as those which, in the past, succeeded in enlarging its reach from manual workers to the working class, and then from the working class to other discriminated groups, expanding with the same stroke its normative core from working conditions to health, education, housing, and on to broader societal issues of justice, authority, discrimination, and inclusion. But it would also reconnect with its original program of economic equality, since inequality cuts much deeper at global than at local scale. It would have, therefore, to espouse a new universalistic, inclusive, and egalitarian vision of society.

Such an approach is immediately confronted with the problem of gaining the support of a solid social constituency to back its mundane counterpart. Such a solution would have to tackle jointly the economic, cultural, and social consequences of globalization, since globalization is deeply responsible for the radicalization of the three dilemmas. Indeed, as the world has become increasingly interconnected, social, economic, and environmental problems have taken on a global dimension that immediately gets to the heart of the social-democratic project, given its universalistic commitment to equality, anti-discrimination, peace, and respect for the environment and future generations. While this global orientation seems to be inescapable for normative as well for mundane reasons, it adds another difficulty to the renewal of the social-democratic project. Indeed, whereas in the era of globalization the normative goals of social democracy can be met only by addressing global circumstances, its mundane counterpart continues to operate within the borders of national states. If, therefore, struggling for global justice and reducing economic inequality throughout the world seems to be the way to go, the problem emerges of how to empower the mundane forces that would have to pursue it. As social democracy cannot ignore the emancipatory side of globalization without reneging on its normative aspirations, the most plausible solution would require turning globalization into a powerful ally to overcome the three dilemmas at the level of national politics.

A viable strategy consistent with the third scenario will need to combine several conditions. On the one hand, we have seen that the social-democratic project cannot be pursued in the absence of a generous welfare state. Yet the state's fiscal crisis and 
demographic decline prevent its expansion and exacerbates conflicts of interest among diverse categories of claimants. On the other, migration flows and globalization, while furthering the emancipatory social-democratic project by contributing to reduce global economic inequality, have amplified the economic and cultural divide that splits the social-democratic constituency. So far, middle classes have mostly been in support of these trends for ideational as well as for material reasons, whereas working classes have opposed them, again for ideational as well as economic reasons. Therefore, the challenge social-democracy must tackle, if it wants to reconstitute the solid social constituency that is needed to enter a fourth phase, is how to devise patterns of globalization and migration likely to appeal also to the working classes. That would require envisioning a new narrative for the future incorporating working class people into the global economy and into a complex and pluralistic society.

This is not the place to assess the likelihood of such an attempt, nor to devise the better strategies to pursue it. Yet if my analysis is correct, any attempt to bring the social-democratic project into its fourth phase will have to reckon with this framework. Table 2 below actualizes Table 1 by including a new column that syntesizes, in a still speculative way, the distinctive features that may charachterize the fourth phase of the social-democratic project.

Table 2. Social-democracy's four phases

\begin{tabular}{|l|l|l|l|l|}
\hline & Till WWII & WWII to mid-70s & Mid-70 to today & $21^{\text {st }}$ century \\
\hline Normative core & Economic equality & Social inclusion through & $\begin{array}{l}\text { Anti- } \\
\text { athoritarianism, } \\
\text { environmentalism, } \\
\text { pacifism. }\end{array}$ & Global Justice \\
\hline Mundane support & Workers' unions & Social-democratic parties & $\begin{array}{l}\text { New Left parties and } \\
\text { social movements }\end{array}$ & $\begin{array}{l}\text { Environmental } \\
\text { parties, } \\
\text { transnational } \\
\text { NGOs, new liquid } \\
\text { actors }\end{array}$ \\
\hline $\begin{array}{l}\text { Major social } \\
\text { constituency }\end{array}$ & Industrial workers & Working class & $\begin{array}{l}\text { New middle class } \\
\text { Area of improvement transnational } \\
\text { alliances }\end{array}$ \\
\hline $\begin{array}{l}\text { Areans } \\
\text { Working conditions }\end{array}$ & $\begin{array}{l}\text { Health, education, } \\
\text { housing }\end{array}$ & $\begin{array}{l}\text { New social risks, } \\
\text { non-economic } \\
\text { discrimination }\end{array}$ & $\begin{array}{l}\text { Global phenomena, } \\
\text { mostly related to } \\
\text { work and } \\
\text { environment }\end{array}$ \\
\hline
\end{tabular}

\section{Conclusion}

It is now time to come back to Przeworski's electoral dilemma. Przeworski was among the firsts to observe that to gain electoral majorities, social-democratic parties are forced to seek electoral support beyond their class-based constituency. In 
Przeworski's reading, this process leads to a dilemma because it forces socialdemocratic parties to dilute their message, losing as a consequence the benefits arising from fidelity with a class-based identity. But this move has an additional implication, that Prezworski did not consider, that is to say, the fact that through this process the normative core of the social-democratic project has undergone a deep transformation, which to some extent solves Przeworski's dilemma by fidelizing the middle classes, only to plunge social-democratic parties into other dilemmas. Indeed, the new classes coopted by social-democratic mundane politics have brought with them not only new material interests - access to existing welfare benefits, demands for new benefits - but also a new interpretation of the social-democratic project itself, emphasizing values that so far had played only a marginal role.

This century-long process has deeply transformed not only mundane actors and social constituencies, but also social-democracy's ideational core. If this is true, then a major implication is that, whatever one thinks of New Left and Third Way-style politics, social-democratic parties cannot return to redistributive politics as usual because the new post-materialist values have become an essential ingredient of the ideational core of social democracy, so that middle class support has become not only a mundane but also an ideational necessity. Certainly, what the new middle class has brought to social democracy is not mere electoral support as Prezworski and others have contended, but also a new vision of the emancipatory project itself. In that sense, the return to an economy-based left politics centered on working class support is blocked for ideational as well as mundane reasons: not only will such a move electorally fail, as Prezworski predicted more than 30 years ago, but more significantly, it would imply a deep betrayal of the social-democratic project as we know it today. This is why the second scenario is intrinsically unstable and in the end unworkable, which leaves us with only two plausible scenarios: demise and renewal.

A major implication of this conclusion is that contemporary left-wing populist parties have two possible options ahead of them. Either they will be able to promote a new project marked by significant discontinuity with the social-democratic one, or they will reduce themselves to a mere stylistic variant of it $^{27}$. Of course, there is nothing intrinsically dramatic in the demise of the social-democratic project, if not for its supporters. Indeed, as the history of liberalism has shown, liberalism's decline has been the enabling condition for the affirmation of a more robust and expansive emancipatory project. Yet for those who embrace the social-democratic project to its full breadth, there is something disturbing about the offhand way in which left-wing populists dismiss entrenched social-democratic values such as European integration, pluralism, constitutional warranties, and the political mediation of intermediary associations, as well as in their flirtation with autoritarian leaders such as Putin or Maduro.

\footnotetext{
${ }^{27}$ I discuss this alternative at greater length in Frega, 2020.
} 
It is not the task of this paper to flesh out an account of how the ideational and the mundane sides of the social-democratic project are most likely to be reconciled. The future is still open and the task of drafting the blueprint for a fourth stage of the social-democratic project belongs to the broader society. What this paper seeks to show is that, whatever the solution, only a new form of dialectical interplay between the mundane and the ideational will free the social-democratic project from the plight of the three dilemmas, and this not only for mundane reasons of electoral politics, but also to achieve its deepest normative goals. As I have contended, if the viability of any emancipatory project requires it to combine an ideational core with a social constituency and a mundane project, the history of social democracy shows clearly that it is only by keeping the ideational and mundane projects in tune that a sufficiently broad social constituency will newly arise.

Acknowledgments For helpful comments, I would like to thank Simon Bornschier, Silja Häusermann, Wolfgang Merkel, Thamy Pogrebinschi, Matteo Santarelli, the participants to the workshop "L'età dei populismi" (Pisa, 28-29th May 2019), and to the International Conference "Ways forward for Democracy (Munich, 24-26th July 2019), as well as the Theory and Society Editors and reviewers.

\section{References}

Afonso, A. and L. Rennwald (2017). Social class and the changing welfare state agenda of populist radical right parties in europe. In P. Manow, B. Palier, and H. Schwander (Eds.), Welfare Democracies and Party Politics: Explaining Electoral Dynamics in Times of Changing Welfare Capitalism, Chapter 7, pp. 171-194. Oxford: Oxford University Press.

Alesina, A. and E. Glaeser (2004). Fighting poverty in the $U S$ and Europe: A world of difference. Oxford: Oxford University Press.

Arditi, B. (2005). Populism as an internal periphery of democratic politics. In F. Panizza (Ed.), Populism and the Mirror of Democracy, Chapter 3, pp. 72-98. Verso London.

Armingeon, K. and G. Bonoli (2007). The politics of post-industrial welfare states: adapting post-war social policies to new social risks. Routledge.

Armingeon, K., C. Isler, L. Knöpfel, and D. Weisstanner (2015). Supplement to the comparative political data set-government composition 1960-2013. Bern: Institute of Political Science, University of Berne.

Arndt, C. (2014). Beating social democracy on its own turf. Scandinavian Political Studies 37(2), 149-170.

Bale, T., C. Green-Pedersen, A. Krouwel, K. R. Luther, and N. Sitter (2010). If you can't beat them, join them? explaining social democratic responses to the challenge from the populist radical right in western europe. Political 
studies 58(3), 410-426.

Bartolini, S. (2000). The Political Mobilization of the European Left. Cambridge: Cambridge University Press.

Benedetto, G., Hix, S., and Mastrorocco, S. (2020). The rise and fall of social democracy, 1918-2017. American Political Science Review, online first.

Beramendi, P., S. Häusermann, H. Kitschelt, and H. Kriesi (Eds.) (2015). The politics of advanced capitalism. Cambridge: Cambridge University Press.

Berman, S. (2006). The primacy of politics: social democracy and the making of Europe's twentieth century. Cambridge: Cambridge University Press.

Berman,S. and Snegovaya, M. (2019). Populism and the decline of social democracy. Journal of Democracy, 30(3):5-19.

Betz, H.-G. (1994). Radical right-wing populism in Western Europe. Houndmills: Palgrave Macmillan.

Bornschier, S. (2010). Cleavage politics and the populist right. Philadelphia: Temple University Press.

Brochmann, G. and A. Hagelund (2012). Immigration policy and the Scandinavian welfare state 1945-2010. Palgrave Macmillan.

Cohen, G. A. (2009). Why not socialism? Princeton: Princeton University Press.

Cohen, J. (2019). What's wrong with the normative theory (and the actual practice) of left populism. Constellations, 26:391-407.

Cowie, J. (2010). Stayin'alive: the 1970s and the last days of the working class. New York: The New Press.

Crouch, C. (2004). Post-democracy. Cambridge: Polity.

Crouch, C. (2018). The Globalization Backlash. New York: John Wiley \& Sons.

De Regt, S., D. Mortelmans, and T. Smits (2011). Left-wing authoritarianism is not a myth, but a worrisome reality. evidence from 13 eastern european countries. Communist and Post-Communist Studies 44(4), 299-308.

Duckitt, J., B. Bizumic, S. Krauss, and E. Heled (2010). A tripartite approach to right-wing authoritarianism: The authoritarianism-conservatismtraditionalism model. Political Psychology 31(5), 685-715.

Eley, G. (2002). Forging democracy: The history of the left in Europe, 1850-2000. Oxford: Oxford University Press.

Emmenegger, P., S. Häusermann, B. Palier, and M. Seeleib-Kaiser (Eds.) (2012). The age of dualization: the changing face of inequality in deindustrializing societies. Oxford: Oxford University Press.

Esping-Andersen, G. (1990). The three worlds of welfare state. Cambridge: Polity Press.

Esping-Andersen, G., D. Gallie, A. Hemerijck, and J. Myles (Eds.) (2002). Why we need a new welfare state. Oxford: Oxford University Press.

Evans, G. (2017). Social class and voting. In K. Arzheimer, G. Evans, and L.-B. Michael (Eds.), The SAGE Handbook of Electoral Behaviour. London: SAGE. 
Federico, C., E. Fisher, and G. Deason (2017). The authoritarian left withdraws from politics: Ideological asymmetry in the relationship between authoritarianism and political engagement. The Journal of Politics 79(3), 1010-1023.

Ferrera, M. (2017). The stein rokkan lecture 2016 mission impossible? reconciling economic and social europe after the euro crisis and brexit. EuropeanJournal of Political Research 56(1), 3-22.

Finchelstein, F. and N. Urbinati (2018). On populism and democracy. Populism 1(1), 15-37.

Flanagan, S. and A.-R. Lee (2003). The new politics, culture wars, and the authoritarian-libertarian value change in advanced industrial democracies. Comparative Political Studies 36(3), 235-270.

Florida, R. (2014). The rise of the creative class-revisited: Revised and expanded. New York: Basic Books.

Frankel, B. (1997). Confronting neoliberal regimes: The post-marxist embrace of populism and realpolitik. New Left Review, 57-92.

Fraser, N. (2013). A triple movement? parsing the politics of crisis after polanyi. $N e w$ Left Review 81, 119-132.

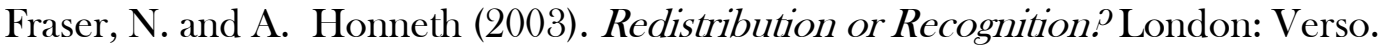

Frega, R. (2019), Pragmatism and the Wide View of Democracy, Palgrave Macmillan, Basingbrooke, 2019.

Frega, R. (2020). Il populismo come l'altro della social-democrazia. In Antonio Masala, (ed.), L'età dei pupulismi. Carocci, Roma, 2020.

Frey, S., P. Gellert, and H. Dahms (2019). Ecologically Unequal Exchange in Comparative and Historical Perspective. Dordrecht: Springer.

Gest, J. (2016). The new minority: White working class politics in an age of immigration and inequality. Oxford: Oxford University Press.

Giddens, A. (1998). The third way: The renewal of social democracy. Cambridge: Polity Press.

Gingrich, J. and S. Häusermann (2015). The decline of the working-class vote, the reconfiguration of the welfare support coalition and consequences for the welfare state. Journal of European Social Policy 25(1), 50-75.

Goodhart, D. (2017). The road to somewhere: the populist revolt and the future of politics. Oxford: Oxford University Press.

Habermas, J. (1986). The new obscurity: The crisis of the welfare state and the exhaustion of utopian energies. Philosophy \& Social Criticism, 11(2):1-18.

Häusermann, S. (2010). The politics of welfare state reform in continental Europe: modernization in hard times. Cambridge: Cambridge University Press.

Hemerijck, A. (2013). Changing welfare states. Oxford: Oxford University Press. Hemerijck, A. (Ed.) (2017). The uses of social investment. Oxford: Oxford University Press. 
Hetherington, M. and J. Weiler (Eds.) (2009). Authoritarianism and polarization in American politics. Cambridge: Cambridge University Press.

Hinnfors, J., A. Spehar, and G. Bucken-Knapp (2012). The missing factor: Why social democracy can lead to restrictive immigration policy. Journal of European Public Policy 19(4), 585-603.

Hochschild, A. R. (2016). Strangers in Their Own Land. A Journey to the Heart of Our Political Divide. New York: The New Press.

Honneth, A. (2015). The Idea of Socialism. Cambridge: Polity Press.

Hooghe, L. and G. Marks (2018). Cleavage theory meets europe's crises: Lipset, rokkan, and the transnational cleavage. Journal of European Public Policy 25(1), 109-135.

Huo, J. (2009). Third way reforms: Social democracy after the golden age. Cambridge: Cambridge University Press.

Inglehart, R. (1990). Culture shift in advanced industrial society. Princeton University Press.

Inglehart, R. and C. Welzel (2005). Modernization, cultural change, and democracy: The human development sequence. Cambridge: Cambridge University Press.

Judis, J. (2016). The Populist Explosion. New York: Columbia University Press.

Kitschelt, H. and P. Rehm (2014). Occupations as a site of political preference formation. Comparative Political Studies 47(12), 1670-1706.

Kriesi, H., E. Grande, R. Lachat, M. Dolezal, S. Bornschier, T. Frey, et al. (2008). West European politics in the age of globalization. Cambridge: Cambridge University Press.

de La Torre, C. (2019). Is left populism the radical democratic answer? Irish Journal of Sociology, 27(1):64-71, 2019.

Lavelle, A. (2008). The death of social democracy: Political consequences in the 21st century. Aldershot: Ashgate.

Lefkofridi, Z. and E. Michel (2017). The electoral politics of solidarity the welfare agendas of radical right parties. In K. Banting and W. Kymlicka (Eds.), The Strains of Commitment. The Political Sources of Solidarity in Diverse Societies, Chapter 9, pp. 233-269. Oxford: Oxford University Press.

Lefkofridi, Z., M. Wagner, and J. Willmann (2014). Left-authoritarians and policy representation in western europe: Electoral choice across ideological dimensions. West European Politics 37(1), 65-90.

Lindvall, J. and D. Rueda (2014). The insider-outsider dilemma. British Journal of Political Science 44(2), 460-475.

Lipset, S. M. (1959). Democracy and working-class authoritarianism. American Sociological Review, 482-501.

Manow, P., B. Palier, and H. Schwander (Eds.) (2018). Welfare Democracies and Party Politics: Explaining Electoral Dynamics in Times of Changing Welfare Capitalism. Oxford: Oxford University Press. 
Marshall, T. (2009). Citizenship and Social Class. In J. Manza and M. Sauder (Eds.), Inequality and Society, pp. 148-154. New York: Norton and Co.

Martin, P. (2013). Le déclin des partis de gouvernement en europe. Commentaire (3), 542-554.

Marx, P. and G. Schumacher (2018). Do poor citizens vote for redistribution, against immigration or against the establishment? a conjoint experiment in denmark. Scandinavian Political Studies 41(3), 263-282.

Mayer, N. (2014). Bring the poor back in! inequalities, welfare and politics. European Political Science 13, 187-200.

Merkel, W., A. Petring, C. Henkes, and C. Egle (Eds.) (2008). Social democracy in power: The capacity to reform. London: Routledge.

Milanovic, B. (2016). Global inequality: A new approach for the age of globalization. Cambridge Ma: Harvard University Press.

Mitchell, W., T. Fazi, et al. (2017). Reclaiming the state. University of Chicago Press Economics Books.

Moffitt, B. (2018). The populism/anti-populism divide in western europe. Democratic Theory 5(2), 1-16.

Morgan, K. (2018). Varieties of electoral dilemmas: partisan jousting over welfare states and immigration in a changing europe. See manow2018welfare, Chapter 5, pp. 119-149.

Moschonas, G. (2002). In the name of social democracy: the great transformation, 1945 to the present. London: Verso.

Mouffe, C. (2005). On the Political. London: Routledge \& K. Paul.

Mudge, S. (2018). Leftism reinvented: Western parties from socialism to neoliberalism. Cambridge, Ma: Harvard University Press.

Müller, J.-W. (2016). What Is Populism? P Philadelphia: University of Pennsylvania Press.

Norris, P. and R. Inglehart (2019). Cultural backlash: Trump, Brexit, and authoritarian populism. Cambridge: Cambridge University Press.

Oesch, D. (2006). Redrawing the class map: Stratification and institutions in Britain, Germany, Sweden and Switzerland. Basingstoke: Palgrave Macmillan.

Oesch, D. and L. Rennwald (2018). Electoral competition in europe's new tripolar political space: Class voting for the left, centre-right and radical right. European journal of political research 57(4), 783-807.

Ottonelli, V. and T. Torresi (2019). Temporary migration projects, special rights and social dumping. Ethical Theory and Moral Practice, 1-15.

Piketty, T. (2020). Capital and ideology. Cambridge, MA: Harvard University Press.

Polanyi, K. (1944). The great transformation: Economic and political origins of our time. New York: Farrar and Rinehart.

Przeworski, A. (1986). Capitalism and social democracy. Cambridge: Cambridge University Press. 
Ray, J. (1974). Do authoritarians hold authoritarian attitudes? Human Relations (29), 307-325.

Rueda, D. (2007). Social democracy inside out: Partisanship and labor market policy in advanced industrialized democracies. Oxford University Press on Demand.

Rydgren, J. (Ed.) (2012). Class politics and the radical right. London: Routledge.

Sassoon, D. (2010). One Hundred Years of Socialism. London: I. B. Tauris.

Shils, E. (1954). Authoritarianism: Right and left. In R. Christie and M. Jahoda (Eds.), Studies in the Scope and Method of "The Authoritarian Personality". Glencoe: Free Press.

Spies, D. (2013). Explaining working-class support for extreme right parties: A party competition approach. Acta Politica 48(3), 296-325.

Stenner, K. (2005). The authoritarian dynamic. Cambridge University Press.

Stjernø, S. (2009). Solidarity in Europe: The history of an idea. Cambridge: Cambridge University Press.

Streeck, W. (2014). Buying Time: The Delayed Crisis of Democratic Capitalism. London: Verso Books.

Thomassen, J. (2012). The blind corner of political representation. Representation 48(1), 13-27.

la Torre, C. de la (2019). Is left populism the radical democratic answer? IrishJournal of Sociology, 27(1), 64-71.

Wagner, P. (2016). Progress: a reconstruction. Cambridge: Polity Press.

Wallerstein, I., R. Collins, M. Mann, G. Derluguian, and C. Calhoun (2013).

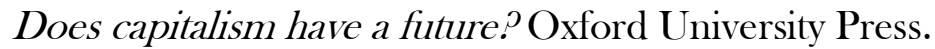

Williams, J. (2017). White working class: Overcoming class cluelessness in America. Cambridge Ma: Harvard Business Press. 